\title{
Análisis filogenético de las cepas de rotavirus y virus de la hepatitis A encontradas en agua de consumo en el municipio de Quibdó, Chocó
}

\author{
Sandra Moreno', Mónica Viviana Alvarado², Andrea Bermúdez², María Fernanda Gutiérrez ${ }^{3}$
}

\footnotetext{
${ }^{1}$ Maestría en Ciencias Biológicas, Pontificia Universidad Javeriana, Bogotá, D.C., Colombia

${ }^{2}$ Laboratorio de Virología, Pontificia Universidad Javeriana, Bogotá, D.C., Colombia

${ }^{3}$ Facultad de Ciencias, Pontificia Universidad Javeriana, Bogotá, D.C., Colombia
}

Introducción. Quibdó, capital del departamento del Chocó, se ha caracterizado por ser una de las regiones más deprimidas en Colombia. La presencia de virus entéricos tipo rotavirus y virus de la hepatitis A en el agua de consumo, además de ser un indicador de su mala calidad, es una importante fuente de contaminación para los individuos que la consumen.

Objetivo. Demostrar la presencia de estos dos agentes virales en el agua de consumo para contribuir con la explicación de la morbilidad por enfermedad diarreica aguda y hepatitis en la región, y aclarar que el origen de estos virus es por contaminación de desechos humanos más que por la materia fecal de bovinos o porcinos.

Materiales y métodos. Se procesaron 4.000 litros de agua que se llevaron a ultrafiltración tangencial y a centrifugación con filtros Centriprep Ultracel YM-50. Se aplicó la prueba de RTPCR a 60 muestras de agua no tratada y a 20 muestras de agua tratada por el acueducto. Las muestras positivas fueron secuenciadas y con el análisis de dichas secuencias se elaboraron árboles filogenéticos.

Resultados. Seis de las muestras resultaron positivas para rotavirus y dos más para virus de la hepatitis A. Éstos aparecieron tanto en aguas tratadas como no tratadas. Los análisis filogenéticos demostraron que el rotavirus pertenece al serotipo G2 humano y que el virus de la hepatitis A fue también de origen humano.

Conclusión. El agua analizada presenta un alto nivel de contaminación, demostrado por la presencia de virus patógenos para el hombre.

Palabras claves: rotavirus, virus de la hepatitis A, contaminación del agua, filogenia, diarrea.

DNA sequence analysis indicates human origin of rotavirus and hepatitis $A$ virus strains from western Colombia

Introduction. Quibdó, the capital of Chocó Province, is one of the poorest cities in Colombia. Enteric viruses such as rotavirus and hepatitis A virus was found to occur commonly in city drinking water and indicated poor water quality and high risk of becoming infected. The source of these viruses was unknown, but humans and cattle were suspect sources.

Objective. City water was assessed to determine source and persistence of diarrhea and hepatitis among the human populations in the environs of Quibdó.

Material and methods. Four thousand liters of water were collected, filtered by tangential ultrafiltration and centrifuged in Centriprep Ultracel YM-50 tubes. Sixty samples of untreated and 20 of treated water were probed by RT-PCR.

Results. Six samples were positive for rotavirus and 2 for hepatitis A virus in both, treated and non treated water. DNA sequence analysis identified the presence of human G2 rotavirus and human hepatitis A virus.

Conclusion. The evidence indicated a high level of contamination with pathogenic viruses in consumable water sources in Quibdó, Colombia.

Key words: rotavirus, hepatitis A virus, water pollution, phylogeny, diarrhea. 
La presencia de virus entéricos tipo rotavirus y virus de la hepatitis $A$ en el agua de consumo, además de ser un indicador de contaminación, es una posible fuente de infección para los individuos que la consumen (1). Teniendo en cuenta que estos virus son estables en el ambiente, que el comportamiento epidemiológico de las infecciones virales está asociado con las condiciones sociales, ambientales y de higiene de la población, y que el acueducto en el departamento del Chocó presenta deficiencias en la cobertura y la calidad del agua $(2,3)$, se puede suponer que esta agua está actuando como fuente de diseminación de virus.

Se estima que el rotavirus, virus ARN de cadena doble, polisegmentado, carente de envoltura y con una triple cápside, causa 600.000 muertes, aproximadamente, al año alrededor del mundo. Este virus que infecta al hombre, también puede generar pérdidas en ganado bovino y porcino, y puede estar presente en otro tipo de animales, causando en ellos enfermedad diarreica aguda. El virus de la hepatitis A pertenece a la familia Picornaviridae, género Hepatovirus; se ha descrito un solo serotipo y siete genotipos cuya presencia se ha asociado a zonas geográficas. Por pertenecer a esta familia, se encuentra genéticamente relacionado con el virus de la poliomielitis y el de la fiebre aftosa (4-7). La infección por este virus puede no producir síntomas, lo que lleva a subestimar su presencia y a encontrar un porcentaje alto de la población con títulos positivos de anticuerpos en edad adulta (4).

El municipio de Quibdó, capital del departamento de Chocó, ha sido por muchos años una de las zonas mas deprimidas del país, donde se registra una tasa de mortalidad infantil de 90 por cada 1.000 niños nacidos vivos (2), y tiene una población aproximada de 100.000 habitantes,

\section{Correspondencia:}

María Fernanda Gutiérrez, Facultad de Ciencias, Pontificia Universidad Javeriana, Carrera 7 No. 43-82, edificio 50, oficina 313.

Teléfono: 320 8320, extensión 4102; fax: 320 8320, extensión 4021.

mfgutier@javeriana.edu.co

Recibido: 03/07/08; aceptado:01/12/08 de los cuales, menos de $38 \%$ tiene acceso a redes de agua potable; el resto de la población obtiene este recurso de la lluvia y de quebradas que llegan a la región (8). Tanto el agua potable como las aguas lluvia, son almacenadas en tanques subterráneos o recipientes expuestos al medio ambiente que no cumplen con las normas mínimas para garantizar su inocuidad.

Los reportes epidemiológicos entregados por el Departamento Administrativo de Salud y Seguridad Social del Chocó, en su informe de morbilidad por consulta externa y urgencias por grupos de edad en el año 2001, sostienen que la enfermedad diarreica aguda es la tercera causa de morbilidad en la población; el primero y segundo lugar lo ocupan las enfermedades de las vías respiratorias y la hipertensión arterial. Una de las causas por las que se le atribuye este tercer lugar podría ser la presencia de patógenos causantes de diarrea que circulan en el medio ambiente y en el agua de consumo.

Los rotavirus y los norovirus juegan un papel muy importante como causantes de enfermedad diarreica aguda, principalmente en la población infantil. En un estudio realizado por nuestro grupo en el año 2002, se reportó una prevalencia de etiología bacteriana de 16,7\%, parasitaria de $15,8 \%$ y viral de $18,09 \%$, donde los novovirus se encontraron en $10,8 \%$ de los casos, seguidos por los rotavirus del grupo A con $8,1 \%$ (9). Pocos reportes se tienen del impacto epidemiológico del virus de la hepatitis $A$ en el país. Sin embargo, un artículo publicado en el periódico El Espectador en el 2007, manifiesta que para ese año se presentaron 229 casos de hepatitis producidas por virus de la hepatitis $A$ y otro artículo publicado en www.encolombia. com/medicina/infectologia, propone que en el grupo de individuos de 10 a 14 años existe una seropositividad de $62 \%$ contra este virus, lo que demuestra que Colombia estaría catalogada como país de endemia mediana para el virus de la hepatitis $\mathrm{A}$ (10-12).

Con el objeto de demostrar la presencia del rotavirus y el virus de la hepatitis $A$ en el agua de consumo del municipio de Quibdó y determinar el origen de la diseminación viral, se utilizaron 
técnicas de concentración de virus en aguas, se amplificaron segmentos de genes virales y a las secuencias obtenidas se les hicieron análisis bioinformáticos con herramientas filogenéticas, para determinar si la procedencia de estos virus era de materia fecal de humanos, bovinos o porcinos.

\section{Materiales y métodos}

\section{Población de estudio y muestreo}

Se recolectaron 8 muestras a la semana por un periodo de 10 semanas, para un total de 80 muestras. Los lugares del muestreo fueron la bocatoma del río Cabí, la planta potabilizadora de agua en Quibdó, una casa seleccionada al azar y cinco barrios del municipio (cuadro 1). En cada punto del muestreo se recolectaron 5 litros de agua en recipientes limpios para un total de 4.000 litros. Debido a que el proceso de potabilización implementado presenta deficiencias, el agua tratada en el acueducto no se consideró como agua potable.

\section{Concentración y purificación viral}

Para determinar la concentración y la purificación de los posibles virus presentes, inicialmente se pasaron 5 litros de agua por membranas depuradoras y esterilizadoras (Opticatm 4" Capsule Disposable Cartridge, pore size 0,8 y $0,2 \mu \mathrm{m}$ Nominal, Millipore). Un litro de este producto se sometió a ultrafiltración tangencial en membrana Millipore (Prep/Scale ${ }^{T M}$ TFF Cartridge $1 \mathrm{ft}^{2}$ ) y los $20 \mathrm{ml}$ obtenidos después de la ultrafiltración se centrifugaron en tubos Centriprep Ultracel YM-50 Millipore, hasta obtener los virus en un volumen final de $3 \mathrm{ml}$ de agua, los cuales se dividieron en alícuotas y se almacenaron $\mathrm{a}-20^{\circ} \mathrm{C}$ hasta la detección viral.

\section{Extracción del ARN viral y determinación de virus de la hepatitis $A$ y rotavirus en el agua}

Para la extracción del ARN viral se utilizó como reactivo trizol $\mathrm{R}$ (Invitrogen) y se siguieron las instrucciones propias del reactivo. La detección del genoma viral se inició con la enzima MML-V (Moloney Murine Leukaemia Virus), que es una enzima con actividad de transcriptasa inversa y con iniciador al azar como cebador de amplificación.

El programa para la transcripción inversa para los dos virus fue: $97^{\circ} \mathrm{C}$ por cinco minutos, $70^{\circ} \mathrm{C}$ por cinco minutos para la desnaturalización del ARN viral y $42^{\circ} \mathrm{C}$ por una hora para la polimerización de nucleótidos de ADN. Al final, se elevó la temperatura a $95^{\circ} \mathrm{C}$ por cinco minutos para la elongación final y formación del ADNc. La amplificación del ADNc se realizó con la enzima Taq polimerasa (Invitrogen). Los iniciadores para el virus de la hepatitis A fueron HAVS y HAVA, que amplifican una región de 247 $\mathrm{pb}$, aproximadamente, situada entre los genes VP1 y VP3, correspondientes a las proteínas de cápside viral (HAV Primer S, nucleótidos 2.1672.192, 5` 5'-GTT TTG CTC CTC TTT ATC ATG CTA TG -3 y el HAV Primer As, nucleótidos 2.413 a 2.389, 5'-GGA AAT GTC TCA GGT ACT TTC TTT G -3') $(13,14)$.

El proceso de amplificación del material genético se realizó con desnaturalización previa de $94^{\circ} \mathrm{C}$ por cinco minutos, desnaturalización de $94^{\circ} \mathrm{C}$ por un minuto, hibridación a $50^{\circ} \mathrm{C}$ por 45 segundos,

Cuadro1. Lugares en Quibdó donde se realizó el muestreo.

\begin{tabular}{llll}
\hline Punto de muestreo & Fuente de abastecimiento & Origen del agua & Lugar donde se recolectó \\
\hline Planta potabilizadora & Potable - tratada & Acueducto & Tanque de almacenamiento \\
Casa a 300 m del acueducto & Potable - tratada & Acueducto & Llave de la casa \\
Bocatoma & Impotable sin tratar & Bocatoma del río Cabí & Río \\
Barrio El Poblado & Impotable sin tratar & Lluvias & Tanque de $1.000 \mathrm{~L}$ \\
Barrio El Jardín & Impotable sin tratar & Lluvias & Tanque subterráneo \\
Barrio Montebello & Impotable sin tratar & Lluvias & Quebrada \\
Barrio El Reposo & Impotable sin tratar & Lluvias & Tanque en una casa \\
Barrio Las Américas & Impotable sin tratar & Lluvias & Tanque subterráneo
\end{tabular}


extensión de $72^{\circ} \mathrm{C}$ por un minuto y extensión final de $72^{\circ} \mathrm{C}$ por diez minutos después de terminar los 35 ciclos de amplificación. Los productos de la amplificación se evidenciaron por la aparición de una banda de $247 \mathrm{pb}$ en gel de electroforesis.

Para identificar el rotavirus se amplificaron dos segmentos del genoma: un segmento del gen que codifica para la cápside intermedia VP6, con el cual se buscó identificar la presencia viral, y el otro segmento que codifica para la proteína externa VP7, con el que se logra tipificar el rotavirus. Los iniciadores que se usaron para el segmento de VP6, amplifican una región de 379 pb desde el nucleótido 747 al 1.126 y fueron VP6-F (sentido) (5' GACGGVGCRACTACATGGT 3') (nt 747-766) y VP6-R (antisentido) (5'GTCCAATTCATNCCTGGTGG 3') (nt 1.126-1.106) (15).

El proceso de amplificación del material genético se realizó con una desnaturalización previa a $94^{\circ} \mathrm{C}$ por dos minutos, desnaturalización a $94^{\circ} \mathrm{C}$ por 30 segundos, hibridación a $58^{\circ} \mathrm{C}$ por 30 segundos y extensión a $72^{\circ} \mathrm{C}$ por un minuto. Los tubos de reacción se dejaron en el termociclador por 40 ciclos, al cabo de los cuales se llevaron a una extensión final de $72^{\circ} \mathrm{C}$ por siete minutos. La electroforesis para ambos segmentos de genoma viral se realizó en el gel de agarosa al 1,5\% con una concentración de bromuro de etidio de $5 \mathrm{mg} / \mathrm{ml}$.

De la región que codifica la proteína VP7 se amplificó un segmento de 1.062 pb usando los iniciadores Beg9b 5'-GGCTTTAAAAGAGAGAA TTTCCGTCTGG-3', que se localizan en el genoma entre los nucleótidos 1 y 28 nt y End9b 5'GGTCACATCATACAATTCTAATCTAAG-3' que se localiza en el genoma entre los nucleótidos 1.062 y 1.036 (15). El proceso de amplificación del material genético se realizó con una desnaturalización previa a $94^{\circ} \mathrm{C}$ por cinco minutos, desnaturalización a $94^{\circ} \mathrm{C}$ por un minuto, hibridación a $42^{\circ} \mathrm{C}$ por dos minutos, extensión a $72^{\circ} \mathrm{C}$ por un minuto, 35 ciclos y extensión final de $72^{\circ} \mathrm{C}$ por siete minutos.

Los controles de prueba fueron un control negativo en el cual se utilizó agua Milli- $Q$ y un control positivo, que para el virus de la hepatitis $A$ fue la cepa HM-175 cultivada previamente en la línea celular FRhK-4, donada por el Laboratorio de Virología del Instituto de Ciencias Biomédicas de la Universidad de São Paulo. Para el rotavirus, se utilizó como control positivo una alícuota viral previamente obtenida, tipificada y donada por el Laboratorio de Virología del Instituto Nacional de Salud.

\section{Secuenciación y análisis filogenético}

Los segmentos virales amplificados fueron enviados a la corporación Macrogen, Corea, para su secuenciación. El análisis de las secuencias se realizó utilizando los programas FinchTV (análisis de cromatogramas) y CLC (obtención secuencias consenso). Para el análisis filogenético, las secuencias fueron alineadas en el formato FASTA en el software Clustal X. Las relaciones filogenéticas fueron construidas en el programa MEGA 4 (Molecular Evolutionary Genetics Analysis), usando el algoritmo de Neighbourjoining utilizando como método de distancia Kimura-2-parámetros. La robustez se validó estadísticamente con un bootstrap de 600 réplicas.

\section{Resultados}

\section{Presencia viral en las muestras de agua}

De 80 muestras recogidas, en $10 \%(8 / 80)$ se demostró la presencia de alguno de los dos segmentos virales buscados: seis muestras con el segmento génico correspondiente a un pedazo de la proteína VP6 del rotavirus $(7,5 \%)$ y dos muestras con el segmento correspondiente al genoma de virus de la hepatitis A $(2,5 \%)$.

En el cuadro 2 se presentan los resultados con el porcentaje de muestras positivas y negativas dependiendo de la fuente de abastecimiento, donde se observa que, en agua no tratada, se encontraron las seis muestras positivas para el segmento correspondiente al gen de VP6 del rotavirus y uno para el segmento génico de los virus de la hepatitis $A$, mientras que en aguas tratadas por el acueducto, se encontró el segundo de los virus de la hepatitis A (figura 1, muestra S2P3).

Para el segmento génico correspondiente a la proteína VP6 se encontraron seis muestras positivas, todas pertenecientes a puntos sin 
cobertura del acueducto; tres de estas muestras pertenecían al barrio Montebello durante las semanas 2, 5 y 10, una al barrio El Poblado en la semana 7 , otra al barrio El Jardín en la semana 6 y la última al barrio Las Américas en la semana 2 (cuadro 3). Para el gen que codifica la proteína VP7, amplificaron sólo tres de las seis muestras positivas para VP6, todas reportadas en el barrio Montebello (figura 2). Estas tres muestras también fueron secuenciadas y analizadas filogenéticamente.

\section{Caracterización molecular y determinación del origen de los virus encontrados en el agua}

De las seis muestras positivas por reacción en cadena de la polimerasa en tiempo real (RTPCR) para el segmento génico correspondiente a VP6 del rotavirus, en sólo tres se logró suficiente cantidad de material amplificado para obtener el segmento analizable y sólo dos de estas secuencias presentaron un electroferograma de óptima calidad para ser analizadas con herramientas bioinformáticas.

Al incluir las dos secuencias en el programa BALST $\mathrm{NBCl}$, se encontró una homología de más de $98 \%$ con cepas de rotavirus humano genotipo G2, motivo por el cual las cepas de referencia seleccionadas del banco de datos fueron en su mayoría tipo G2. En la figura 3 se presenta el árbol filogenético con las dos cepas de rotavirus que se agrupan con cuatro secuencias de rotavirus $\mathrm{G} 2$, en un grupo distinto a las otras cepas incluidas para la elaboración del árbol: G8, G9, G4, G1 y G3.

Para elaborar el árbol filogenético con las secuencias de virus de la hepatitis $\mathrm{A}$, también se realizó un BLAST en el cual se encontró una homología mayor de $97 \%$ con respecto a cepas de virus de la hepatitis A humanas. Para seleccionar las cepas de referencia y elaborar el árbol, se escogieron aquéllas a las que se les hubiera amplificado la región VP1/VP3. Como raíz, se colocó una secuencia del virus de la fiebre aftosa, aislado en Camerún (figura 4).

\section{Discusión}

Numerosos estudios han demostrado la asociación de los brotes de enfermedad diarreica aguda con virus entéricos presentes en el agua de consumo. Entre los virus reportados, el rotavirus y el virus de la hepatitis $A$ juegan un papel importante por ser unos de los agentes etiológicos más frecuentes $(1,16,17)$. Si bien la eliminación de virus de las aguas es un proceso difícil y costoso, Deetz y colaboradores y Keswick y colaboradores, en 1984, demostraron que un adecuado tratamiento del agua logra eliminar, aproximadamente, $94 \%$ de los virus presentes en ella $(18,19)$.

La presencia de rotavirus o de virus de la hepatitis A en $10 \%$ de muestras de agua en Quibdó,

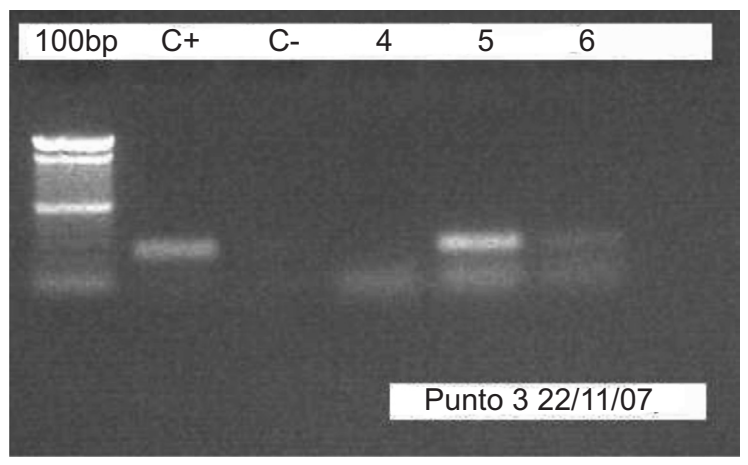

Figura 1. Amplificación del segmento de 213 pb del virus de la hepatitis A. La muestra que aparece positiva es la S2P3: semana 2, muestra tomada de la bocatoma.

Cuadro 2. Número de muestras y porcentaje de muestras positivas para rotavirus y virus de la hepatitis A.

\begin{tabular}{|c|c|c|c|c|c|c|c|}
\hline \multirow[t]{2}{*}{ Fuente de abastecimiento } & \multirow[t]{2}{*}{$\begin{array}{l}\text { Muestras } \\
(\mathrm{N})\end{array}$} & \multicolumn{2}{|c|}{$\begin{array}{l}\text { Muestras } \\
\text { positivas }\end{array}$} & \multicolumn{2}{|c|}{$\begin{array}{l}\text { Muestras positivas } \\
\text { para rotavirus }\end{array}$} & \multicolumn{2}{|c|}{$\begin{array}{c}\text { Muestras positivas } \\
\text { para virus de la hepatitis } A\end{array}$} \\
\hline & & $\mathrm{n}$ & $\%$ & $n$ & $\%$ & $n$ & $\%$ \\
\hline Sin tratar & 6 & 07 & 8,75 & 6 & 7,5 & 1 & 1,25 \\
\hline Tratada & 20 & 1 & 1,25 & 0 & 0 & 1 & 1,25 \\
\hline Total & 80 & 8 & 10 & 6 & 7,5 & 2 & 2,5 \\
\hline
\end{tabular}


Cuadro 3. Muestras de aguas positivas para rotavirus y virus de la hepatitis A. El número de muestras tomadas cada semana fue de ocho.

\begin{tabular}{|c|c|c|c|c|c|c|c|c|c|c|}
\hline Semana/lugar & s1 & S2 & S3 & S4 & S5 & S6 & s7 & S8 & s9 & S10 \\
\hline Planta (P1) & - & - & - & - & - & - & - & - & - & - \\
\hline Casa a 300 m (P2) & - & - & - & - & - & HAV & - & - & - & - \\
\hline Bocatoma (P3) & - & HAV & - & - & - & - & - & - & - & - \\
\hline Barrio El Poblado (P4) & - & - & - & - & - & - & $\mathrm{RV}$ & - & - & - \\
\hline Barrio El Jardín (P5) & - & - & - & - & - & $\mathrm{RV}$ & - & - & - & - \\
\hline Barrio Montebello (P6) & - & RV & - & - & - & RV & - & - & RV & - \\
\hline Barrio El Reposo (P7) & - & - & - & - & - & - & - & - & - & - \\
\hline Barrio Las Américas (P8) & - & - & - & - & - & - & - & - & - & - \\
\hline $\begin{array}{l}\text { Total de muestras positivas para } \\
\text { algún virus }\end{array}$ & $0 / 8$ & $2 / 8$ & $0 / 8$ & $0 / 8$ & $0 / 8$ & $3 / 8$ & $1 / 8$ & $0 / 8$ & $1 / 8$ & $0 / 8$ \\
\hline
\end{tabular}

S: semana; (-): negativo para cualquiera de los dos virus; HAV: virus de la hepatitis A; RV: rotavirus

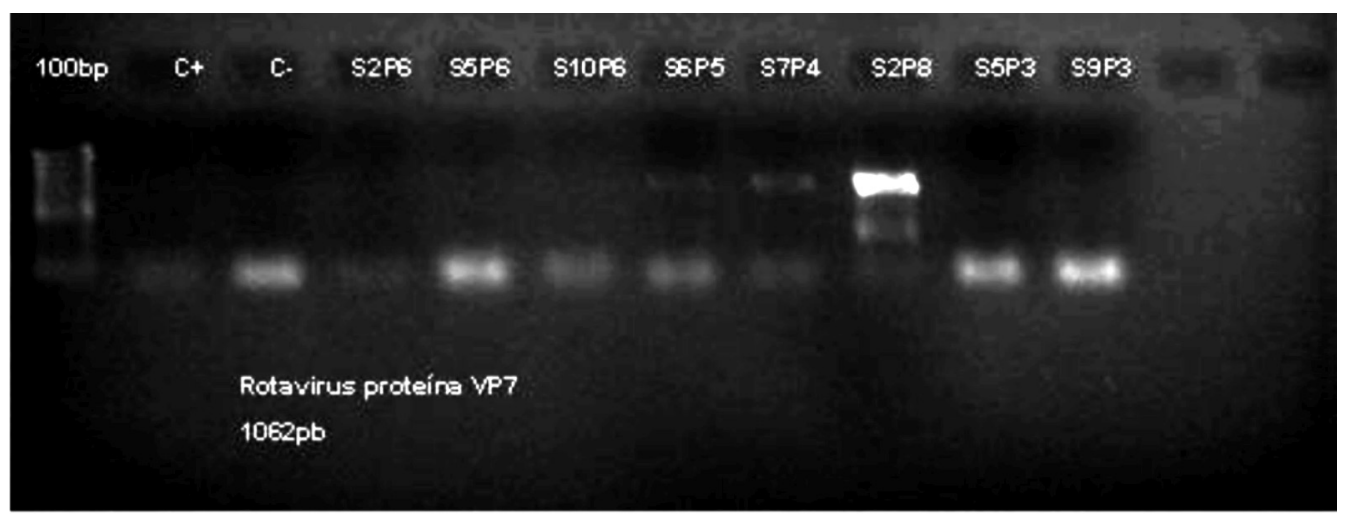

Figura 2. Amplificación del segmento de 1062 pb de VP7 del rotavirus. Aparecen positivas tres muestras, S6P5, S7P4 y S2P8.

S: semana, P:punto

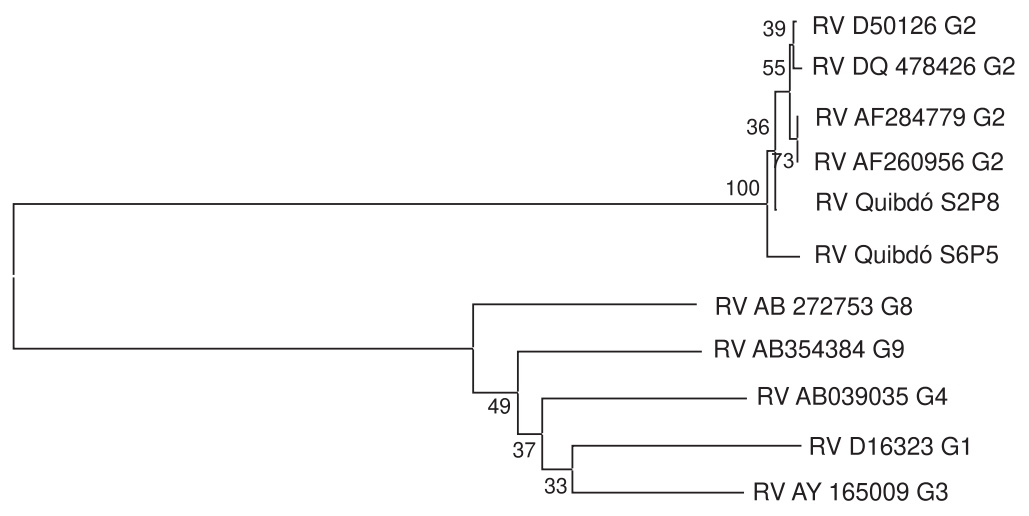

0.05

Figura 3. Análisis filogenético de la secuencia de nucleótidos de los rotavirus encontrados en las aguas del municipio de Quibdó. El árbol filogenético fue elaborado con el método de neighbour joining, al cual se le aplicó un bootstrap de 600 repeticiones. 


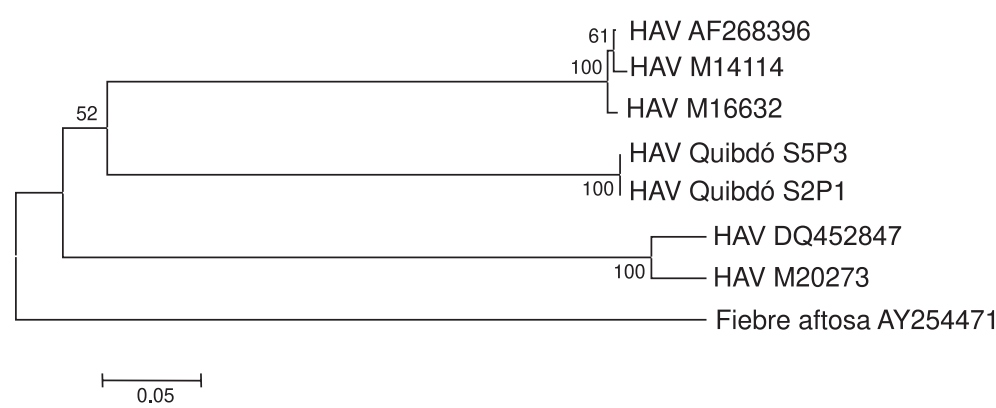

Figura 4. Análisis filogenético de la secuencia de nucleótidos de los virus de la hepatitis $A$ encontrados en las aguas del municipio de Quibdó. El árbol filogenético fue elaborado con el método de neighbour joining, al cual se le aplicó un bootstrap de 600 repeticiones.

podría interpretarse como que uno de 10 vasos de agua que se toma un individuo, puede ser la causa de enfermedad diarreica aguda o hepatitis; éste es un dato alarmante, pues si bien con el hallazgo de un segmento de su ácido nucleico no se puede garantizar su capacidad infecciosa ni la presencia de la partícula viral completa, sí es un indicio de su presencia (20). Por otra parte, los análisis filogenéticos demuestran una similitud mayor de $98 \%$ entre las secuencias obtenidas y las comparadas con las de cepas de virus humanos previamente reportadas, lo cual descarta que estos virus provengan de actividad ganadera 0 avícola.

El método de RT-PCR es útil para detectar virus en el agua. Sin embargo, existen dos obstáculos en su implementación; el primero es la presencia de inhibidores de las enzimas usadas para amplificar el ácido nucleico $(16,17,21)$ y el segundo es que la sensibilidad reportada es de $10^{3}$ partículas $/ \mathrm{ml}$. Ambos obstáculos supondrían la presencia de resultados falsos negativos a lo largo del trabajo, lo cual implicaría que el porcentaje de virus en el agua es aún mayor de $10 \%$. Sin la necesidad de superar estos dos obstáculos, se puede afirmar que el agua de consumo de Quibdó puede actuar como vehículo de transmisión de rotavirus y virus de la hepatitis $A, y$ puede contribuir con los altos índices de morbimortalidad en la población.

La presencia de rotavirus serotipo G2 dentro de una población no es un dato sorpresivo, pues son los rotavirus $\mathrm{G} 1$ a G4 los más reportados $y$ de mayor prevalencia en las poblaciones alrededor del mundo (22). Con respecto al virus de la hepatitis $A$, teniendo en cuenta que la presencia de los siete genotipos se han descrito sobre el segmento VP1/2A (6) y no sobre el segmento secuenciado en este trabajo, no se puede conocer el genotipo al que pertenece; sin embargo, las cepas encontradas cuentan con homologías mayores de $97 \%$ con cepas de virus que infectan humanos. Vale la pena resaltar que existen variaciones en los nucleótidos entre las cepas encontradas en Quibdó con respecto a las reportadas en el Genbank, con una frecuencia mayor a las variaciones encontradas en las cepas de Quibdó. Es por esto que en la topología de los dos árboles, las muestras de Quibdó forman conglomerados independientes, lo que demuestra variaciones menores dadas por eventos evolutivos diferentes a los que presentan las cepas reportadas en el GenBank.

Con los resultados de esta investigación se puede suponer que, en el municipio de Quibdó, tanto el consumo de agua tratada como de no tratada, forma parte de los riesgo de contaminación viral y que los virus encontrados en el agua provienen de fuentes humanas. En caso de buscar alternativas de solución a este problema, se deben mejorar las condiciones generales del acueducto, se debe incrementar la educación para que la población no utilice las fuentes de agua como lugares de depósito de desechos y se debe trabajar arduamente para mejorar el sistema de alcantarillado y el manejo de basuras. Si bien la ausencia de estos virus en el agua no evita que los niños adquieran enfermedad diarreica aguda por esta etiología, si se retrasa el momento de infección, dando a 
los niños mayor tiempo para fortalecerse tanto nutricional como inmunológicamente.

El lograr conjugar la investigación básica con la aplicada y obtener resultados que incidan en el mejoramiento de la calidad de vida de nuestros pobladores, es una ganancia agregada de la investigación. Uno de los objetivos de este trabajo fue aportar evidencias para justificar el origen de un problema de salud que se presenta en la población de Quibdó, que involucra al agua como fuente de transmisión de virus causantes de enfermedades como la diarrea aguda y la hepatitis A. Para esto, se determinaron dos grupos virales en el agua, se presentaron sus porcentajes de aparición y se sugirió que fueron los mismos pobladores los causantes de dicha contaminación. Todo esto corresponde a un trabajo de investigación aplicada a una problemática social. Sin embargo, el entrar a secuenciar segmentos génicos y determinar similitudes filogenéticas con cepas reportadas en bancos mundiales de datos, son herramientas propias de la investigación básica que buscan conocer y describir las moléculas que componen los virus presentes en el medio ambiente. Por este motivo, la discusión de este artículo presenta dos temas, el primero es el impacto social y de salud que generan los resultados presentados y la necesidad de crear estrategias de control al problema sanitario asociado a la presencia de estos virus en el agua, y el segundo tema es analizar los virus presentes en el medio ambiente y el significado de su caracterización filogenética.

\section{Agradecimientos}

Al Laboratorio de Virología del Instituto de Ciencias Biomédicas de la Universidad de São Paulo y al Laboratorio de Virología del Instituto Nacional de Salud por donarnos los controles para las pruebas. A Aura Rosa Manascero por la lectura y correcciones del documento, al microbiólogo Juan Ulloa por supervisar el trabajo técnico y a la gente del municipio de Quibdó por permitirnos recolectar las muestras.

\section{Conflicto de intereses}

Los autores declaramos que no tenemos conflicto de intereses.

\section{Financiación}

Este proyecto fue financiado con recursos propios que le otorga la Pontificia Universidad Javeriana al desarrollo e impulso de la investigación.

\section{Referencias}

1. Bosch A, Guix S, Sano D, Pintó R. New tools for the study and direct surveillance of viral pathogens in water. Curr Opin Biotechnol. 2008;19:295-301.

2. Procuraduría General de la Nación, Ministerio del Medio Ambiente, UNICEF. Agua para la vida, Colombia y el mundo. Panorama nacional: Los niños, el agua y el ambiente sano. La infancia, el agua y el saneamiento básico en los planes de desarrollo departamentales y municipales. Primera edición. Bogotá, D.C.: CMYK Impresiones Ltda.; 2006. p. 18-29.

3. Eltiempo.com/archivo. La tragedia del Chocó. El Tiempo. Enero 2005; Editorial Opinión. Fecha de consulta: 15 de febrero de 2007. Disponible en: http:// www.eltiempo.com/archivo/documento/MAM-1674069

4. Byun K, Kim J, Song K, Baek L, Song J, Park S, et al. Molecular studies: Hepatitis A virus and hepatectomy. Molecular epidemiology of hepatitis A in Korea. J Gastroenterol Hepatol. 2001;16:519-24.

5. Cuthbert JA. Hepatitis A: Old and new. Clin Microbiol Rev. 2001;14:38-58.

6. Costa-Mattioli M, Cristina J, Romero H, Pérez-Bercof R, Casane D, Colina R, et al. Molecular evolution of hepatitis A virus: A new classification based on the complete Vp1 protein. J Virol. 2002;76:9516-25.

7. Fiore A. Hepatitis A transmitted by food. Clin Infect Dis. 2004;38:705-15.

8. Hernández OA. El agua de aquí, es la que cae del cielo. Fecha de consulta: 15 de febrero de 2007. Disponible en: http://www.latarde.com/2007/2/15/nac1.htm

9. Martínez L, Matiz A, Trespalacios AA, Ajami N, Mora $\mathrm{CI}$, Serrano $\mathrm{P}$, et al. Etiología de la enfermedad diarreica aguda en niños menores de 5 años en la población de Quibdó. El calicivirus, un nuevo hallazgo. Pediatría. 2005;40:43-52.

10. Rubio MP, Castro J, Gutiérrez E, Tanaka J. Seroprevalencia de la hepatitis A y varicela en Bogotá, Colombia. Revista Panamericana de Infectología. 2006. Fecha de consulta: 15 de febrero de 2007. Disponible en: http://encolombia.com/medicina/ infectologia/revista panadeinfev4-1-investigaseroprevaha.htm

11. Rodríguez C. Actualización sobre hepatitis virales: Etiología, patogenia, diagnóstico microbiológico y prevención. Rev Cubana Med Gen Integr. 2000;16:574-85.

12. Costa-Mattioli M, Di Napoli A, Ferré V, Billaudel S, Pérez R, Cristina J. Genetic diversity of hepatitis A virus. J Gen Virol. 2003;84:3191-201. 
13. Deng M, Day S, Cliver D. Detection of hepatitis a virus in environmental samples by antigen-capture PCR. Appl Environ Microbiol. 1994;60:1927-33.

14. Brooks H, Gersberg R, Dhar A. Detection and quantification of hepatitis $A$ virus in seawater via realtime RT-PCR. J Virol Methods. 2005;127:109-18.

15. Gouvea V, Glass R, Woods P, Taniguchi K, Clark $\mathbf{H}$, Forrester $\mathbf{B}$, et al. Polymerase chain reaction amplification and typing of rotavirus nucleic acid from stool specimens. J Clin Microbiol. 1990;28:276-82.

16. Dubois E, Hennechart C, Merle G, Burger C, Hmila $\mathbf{N}$, Ruelle S, et al. Detection and quantification by real time RT-PCR of hepatitis A virus from inoculated tap waters, salad vegetables and soft fruits: Characterization of the method performances. Int J Food Microbiol. 2007;117:141-9.

17. Espinosa A, Mazari-Hiriart M, Espinosa R, MaruriAvidal L, Méndez E, Arias C. Infectivity and genome persistence of rotavirus and astrovirus in groundwater and surface water. Water Res. 2008;42:2618-28.
18. Deetz TR, Smith EM, Goyal SM, Gerba CP, Vollet JJ, Tsai $L$, et al. Occurrence of rota-and enteroviruses in drinking and environmental water in a developing nation. Water Res. 1984;18:567-71.

19. Keswick BH, Gerba CP, DuPont HL, Rose JB. Detection of enteric viruses in treated drinking water. Appl Environ Microbiol. 1984;47:1290-4.

20. Gutiérrez M, Alvarado M, Martínez E, Ajami N. Presence of viral proteins in drinkable water-sufficient condition to consider water a vector of viral transmission? Water Res. 2007;41:373-8.

21. Haramoto E, Katayama H, Utagawa E, Ohgaki S. Development of sample storage methods for detecting enteric viruses in environmental water. J Virol Methods. 2008;151:1-6.

22. Duan Z, Li D, Zhang Q, Liu N, Huang C, Jiang X, et al. Novel human rotavirus of genotype G5P(6) identified in a stool specimen from a Chinese girl with diarrhea. J Clin Microbiol. 2007;45:1614-7. 